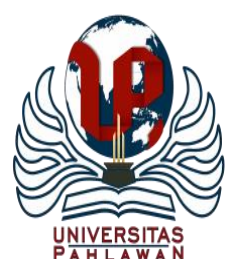

Jurnal Abdidas Volume 2 Nomor 4 Tahun 2021 Halaman 878-883

JURNAL ABDIDAS

http://abdidas.org/index.php/abdidas

\title{
Peningkatan Kompetensi Guru dalam Merancang Media Pembelajaran pada Adaptasi Kebiasaan Baru di SD Kabupaten Buton
}

\author{
Andi Lely Nurmaya $\mathbf{G}^{1}$, $\operatorname{Irsan}^{2}$, Muliati ${ }^{3}$, Ahmad Fuadi ${ }^{4}$ \\ Pendidikan Guru Sekolah Dasar, FKIP, Universitas Muhamadiyah Buton, Indonesia ${ }^{1,2,3,4}$ \\ E-mail: Andiley_nurmaya@yahoo.co.id ${ }^{1}$ Irsanlely@gmail.com $^{2}$ muliatiumb@gmail.com ${ }^{3}$ \\ ahmadf@gmail.com ${ }^{4}$
}

\begin{abstract}
Abstrak
Pandemi Covid-19 berdampak besar pada berbagai sektor, salah satunya pendidikan. Dunia pendidikan juga ikut merasakan dampaknya. Pendidik harus memastikan kegiatan belajar mengajar tetap berjalan, meskipun peserta didik berada di rumah. Solusinya, pendidik dituntut mendesain media pembelajaran sebagai inovasi dengan memanfaatkan media daring (online) Sistem pembelajaran dilaksanakan melalui perangkat personal komputer (PC) atau laptop yang terhubung dengan koneksi jaringan internet. Tujuan dari kegiatan ini adalah peningkatan kompotensi guru dalam merancang media pembelajaran pada adaptasi kebiasaan baru. Secara umum, metode yang digunakan dalam pelatihan ini berupa pelatihan menggunaan Google Classroom sebagai media pembelajaran dimasa pandemik ini. Kegiatan diawali dengan pemberian paparan materi tentang langkahlangkah pembuatan Google Classroom dan manfaatnya. Setelah diberikan materi guru diberikan tugas untuk merancang media pembelajaran sesuai dengan topik yang telah ditentukan. Langkah terakhir adalah peserta mempresentasikan hasil pelatihannya. Hasil dari pelatihan ini berpengaruh signifikan terhadap kemampuan guru.
\end{abstract}

Kata kunci: pandemi, media pembelajaran, google classroom

\section{Abstract}

The Covid-19 pandemic has had a major impact on various sectors, one of which is education. The world of education also feels the impact. Educators must ensure that teaching and learning activities continue, even though students are at home. The solution is that educators are required to design learning media as innovations by utilizing online media. The learning system is carried out through personal computers (PCs) or laptops connected to an internet network connection. The purpose of this activity is to increase the competence of teachers in designing learning media for adapting new habits. In general, the method used in this training is in the form of training to use Google Classroom as a learning medium during this pandemic. The activity begins with providing material exposure about the steps for making Google Classroom and its benefits. After being given the material, the teacher is given the task of designing learning media according to a predetermined topic. The last step is for participants to present the results of their training. The results of this training have a significant effect on the ability of teachers.

Keywords: pandemic, learning media, google classroom.

Copyright (c) 2021 Andi Lely Nurmaya. G, Irsan, Muliati, Ahmad Fuadi

$\triangle$ Corresponding author

Address : Universitas Muhamadiyah Buton

ISSN 2721- 9224 (Media Cetak)

Email : Andiley_nurmaya@yahoo.coid

ISSN 2721- 9216 (Media Online)

DOI : https://doi.org/10.31004/abdidas.v2i4.359 
879 Peningkatan Kompetensi Guru dalam Merancang Media Pembelajaran pada Adaptasi Kebiasaan Baru di SD Kabupaten Buton- Andi Lely Nurmaya. G, Irsan, Muliati, Ahmad Fuadi

DOI: https://doi.org/10.31004/abdidas.v2i4.359

\section{PENDAHULUAN}

Kondisi pandemi Covid-19 ini mengakibatkan perubahan yang luar biasa, termasuk dalam bidang pendidikan. Seolah seluruh jenjang pendidikan dipaksa bertransformasi untuk beradaptasi secara tiba-tiba drastis untuk melakukan pembelajaran dari rumah melalui media daring (online) (Purwati Zisca Diana, Denik Wirawati, 2020). Media pembelajaran dapat menambah kemenarikan tampilan materi sehingga meningkatkan motivasi dan minat serta mengambil perhatian peserta didik untuk fokus mengikuti materi yang disajikan, sehingga diharapkan efektivitas belajar akan meningkat (Sabran \& Sabara, 2019). Ini tentu bukanlah hal yang mudah, karena belum sepenuhnya siap. Problematika dunia pendidikan yaitu belum seragamnya proses pembelajaran, baik standar maupun kualitas capaian pembelajaran yang diinginkan (Agustina \& Jeruk, n.d.).

Hal ini tentu dirasa berat oleh pendidik dan peserta didik. Terutama bagi pendidik, dituntut kreatif dalam penyampaian materi melalui media pembelajaran daring (Utami, 2019). Ini perlu disesuaikan juga dengan jenjang pendidikan dalam kebutuhannya. Dampaknya akan menimbulkan tekanan fisik maupun psikis (mental) (Inggriyani et al., 2019).

Kondisi ini yang dirasakan pada guru-guru di SD N 30 Buton yang terletak di Kecamatan Lasalimu, Kabupaten Buton. Berdasarkan hasil observasi yang dilaksanakan tim kegiatan pengabdian kepada masyarakat menemukan beberapa kendala selama proses pembelajaran daring (online) khususnya media pembelajaran yang akan digunakan. Di samping itu masih ada guru yang belum mampu mengaplikasikan teknologi dalam proses pembelajaran. Ini adalah tantangan berat yang dihadapi guru di sekolah tersebut. Dengan adanya permasalahan tersebut, diperlukan adanya bimbingan dan pelatihan peningkatan kompetensi guru dalam merancang media pembelajaran pada adaptasi kebiasaan baru di Sekolah Dasar Kabupaten Buton.

Sarana dan prasarana di SDN 30 Buton sudah memadai, meskipun jumlahnya masih terbatas misalnya jumlah laptop maupun komputer serta LCD proyektor. Di samping itu jumlah tenaga pengajar atau guru di sekolah tersebut sudah banyak akan tetapi kemampuan SDM dalam mengaplikasikan teknologi dalam pembelajaran masih rendah serta penggunaan media pembelajaran dalam jaringan (online). Terdapatnya beberapa masalah tersebut menunjukkan kualitas yang dimiliki guru masih rendah dan diperlukan adanya bimbingan dan pelatihan.

Terdapatnya guru yang belum mampu merancang media pembelajaran, khususnya media pembelajaran dalam jaringan (online) serta masih adanya guru yang belum mampu mengoperasikan teknologi dalam proses pembelajaran. Permasalahan tersebut menandakan dibutuhkannya suatu kegiatan bimbingan dan pelatihan untuk meningkatkan pengetahuan dan keterampilan guru dalam pembuatan media pembelajaran. Solusi yang ditawarkan pada permasalahan ini adalah melakukan pelatihan peningkatan kompetensi guru dalam transformasi rancangan media pembelajaran pada adaptasi kebiasaan baru di Sekolah Dasar Kabupaten Buton. 
880 Peningkatan Kompetensi Guru dalam Merancang Media Pembelajaran pada Adaptasi Kebiasaan Baru di SD Kabupaten Buton- Andi Lely Nurmaya. G, Irsan, Muliati, Ahmad Fuadi

DOI: https://doi.org/10.31004/abdidas.v2i4.359

Target dalam kegiatan PKM ini adalah peningkatan pemahaman guru dalam merancang media pembelajaran interaktif pada adaptasi kebiasaan baru. Tersedianya media pembelajaran interaktif, serta luaran yang diharapkan dalam kegiatan pengabdian masyarakat ini adalah meningkatnya kompotensi guru dalam merancang media pembelajaran serta laporan sebagai bukti pelaksanaan kegiatan.

\section{METODE}

Pelaksanaan pengabdian masyarakat di SD 30 Kabupaten Buton pada bulan Desember 2020. Kegitan pengabdian ini difokuskan kepada guruguru SD 30 kabupaten Buton dalam meningkatakan kualitas pembelajaran, khususnya dalam merancang media pembelajaran pada pembelajaran daring. Adapun beberapa tahapan yang dilakukan sehingga tujuan kegiatan tersebut dapat tercapai secara maksimal. Tahapan pelaksanaan pengabdian masyakat ini dilakukan beberapa tahap antara lain:

1. Mengidentifikasi permasalahan yang sering dikeluhkan guru dalam proses pembelajaran selama pandemik dengan pihak sekolah.

2. Menyusun materi yang akan digunakan dalam pelaksanaan pengabdian masyarkat.

3. Melakukan pemberian materi pelatihan mengenai perancangan media pembelajaran pada adaptasi kebiasaan baru yang dibantu mahasiswa PGSD.

4. Membagi peserta dalam beberapa kelompok.
5. Menjelaskan software yang digunakan selama mengikuti pelatihan dan fitur-fitur yang digunakan.

6. Meminta guru mendiskusikan topik materi pelajaran yang akan dibuatkan media pembelajaran.

7. Guru menracang media pembelajaran menggunakan software yang telah diajarkan.

8. Guru mempresentasikan media yang telah dibuat di depan peserta pelatihan.

Terdapat beberapa metode yang dilakukan pada pelaksanaan kegiatan pengabdian masyarakat ini dalam peningkatan kompetensi guru dalam merancang media pembelajaran pada adaptasi kebiasaan baru di Sekolah Dasar Kabupaten Buton. Metode tersebut antara lain metode ceramah, diskusi, penugasan, demonstrasi serta presentasi.

\section{HASIL DAN PEMBAHASAN}

Kegiatan pengabdian kepada masyarakat telah dilaksanakan pada bulan Februari 2021 di SD 70 Kabupaten Buton. Kegiatan ini terdiri beberapa tahapan mulai dari kunjugan ke sekolah mitra melalukan obeservasi permasalahan, penyusunan proposal hingga melakukan kegiatan pelatihan

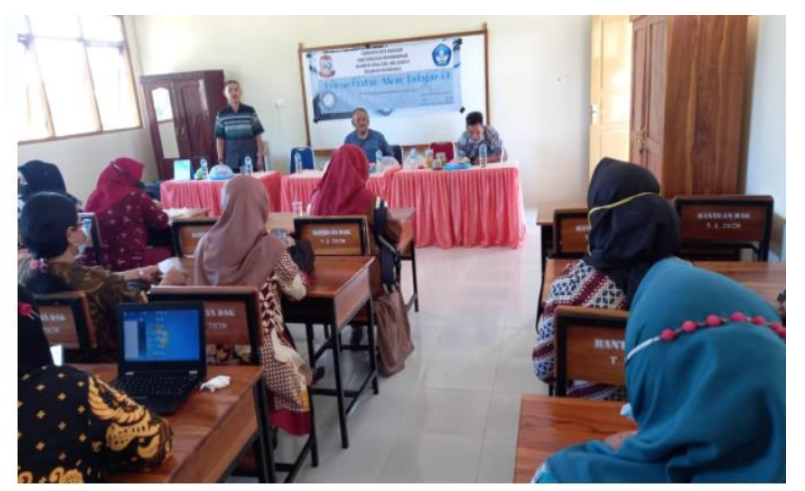




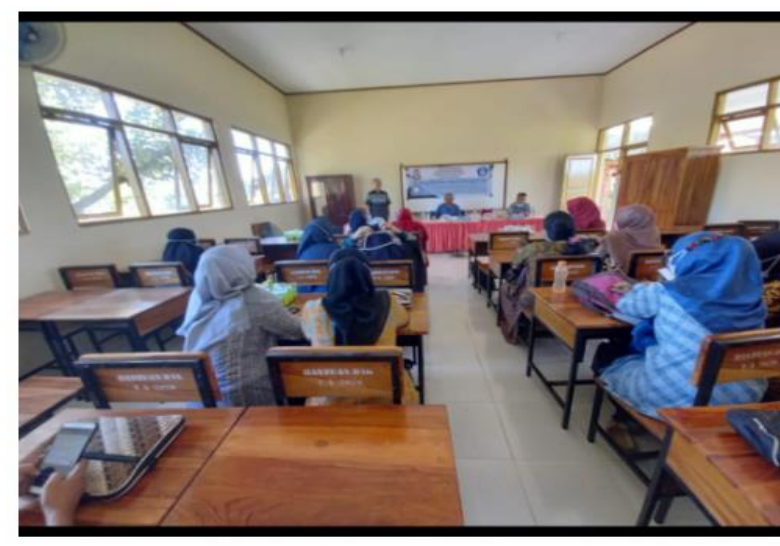

Gambar 1. Kunjugan ke Sekolah Mitra

Sebelum memulai pelatihan, peserta terlebih dahulu mengisi absensi kehadiran sebagai persyaratan administrasi kegiatan pelatihan. Selanjutnya, peserta pelatihan diberikan pertanyaan seberapa besar kemampuan untuk mengoperasikan komputer serta mengakses internet. Untuk menunjang pelatihan, seluruh peserta diberikan modul. Selanjutnya peserta diberikan kesempatan untuk memulai mengeporasikan komputer/laptop untuk membuat media pembelajaran Google Classroom.

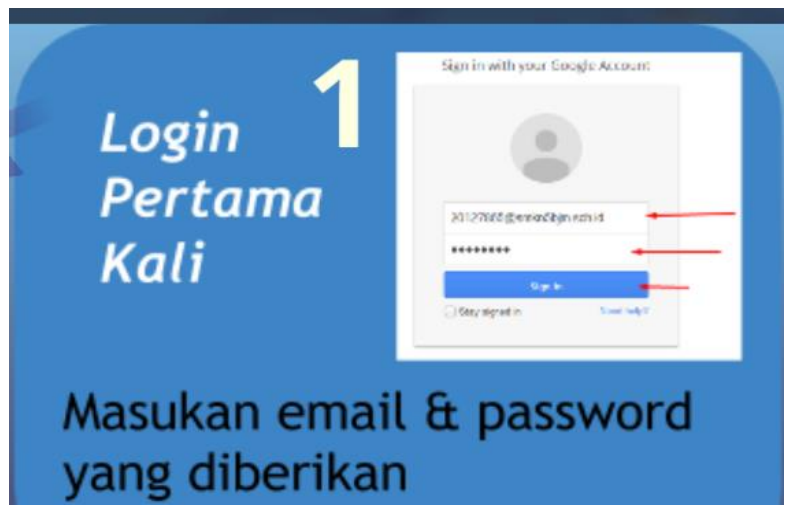

Gambar 2. Langkah Pertama

Langkah pertama adalah harus memastikan peserta memiliki akun Google untuk dapat menggunakan Classroom. Pada pelatihan ini masih terdapat guru yang belum memiliki akun karena itu dibantu dibuatkan oleh pemateri dan mahasiswa.

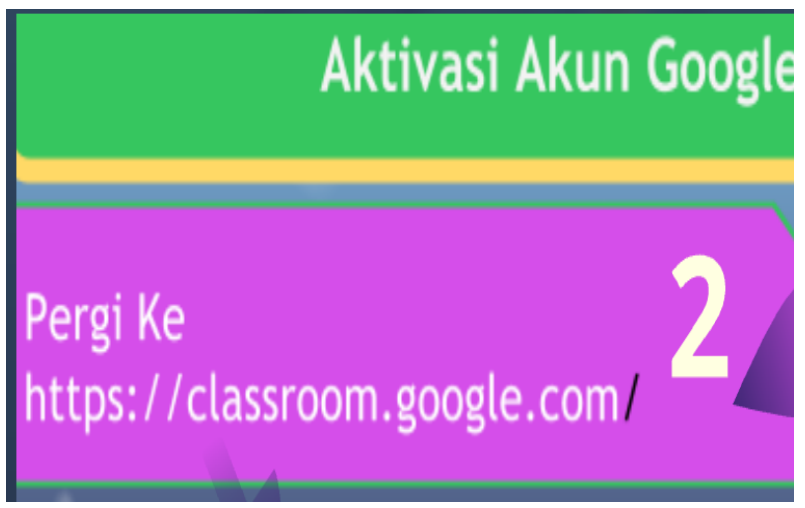

Gambar 3. Langkah Kedua

Langkah kedua adalah membuka aplikasi website (browser) dan masuk ke laman https://classroom.google.com.

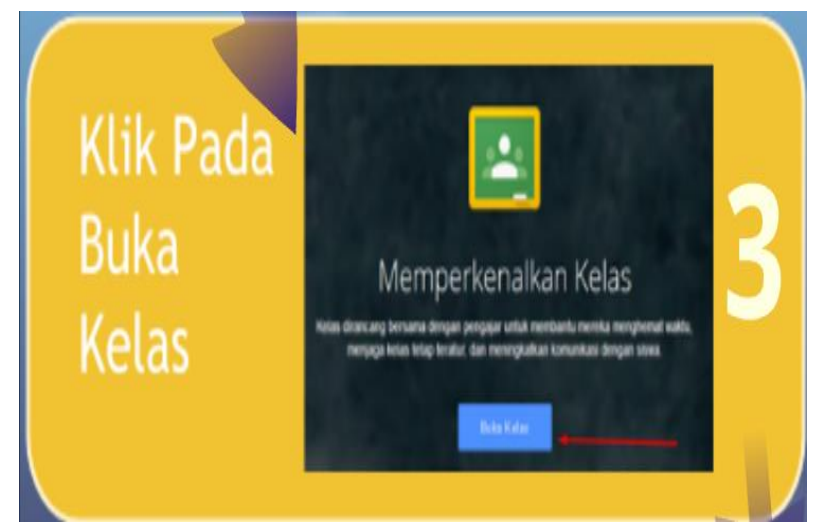

Gambar 4. Langkah Ketiga

Pada pojok atas klik tombol "Buat Kelas" dengan mengisi nama kelas, bagian, mata pelajaran serta ruangan. 
882 Peningkatan Kompetensi Guru dalam Merancang Media Pembelajaran pada Adaptasi Kebiasaan Baru di SD Kabupaten Buton- Andi Lely Nurmaya. G, Irsan, Muliati, Ahmad Fuadi

DOI: https://doi.org/10.31004/abdidas.v2i4.359

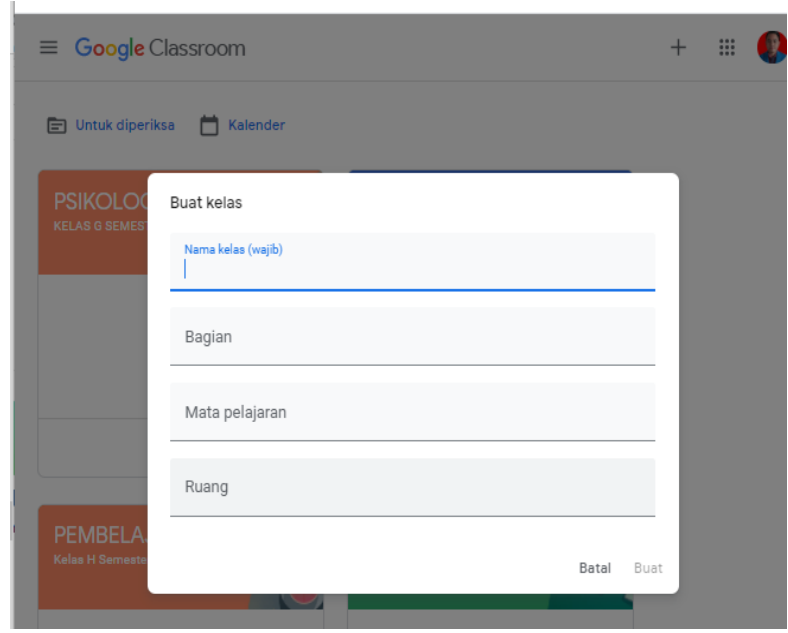

Gambar 5. Langkah Keempat

Pada pojok atas klik tombol "Buat Kelas" dengan mengisi nama kelas, bagian, mata pelajaran serta ruangan

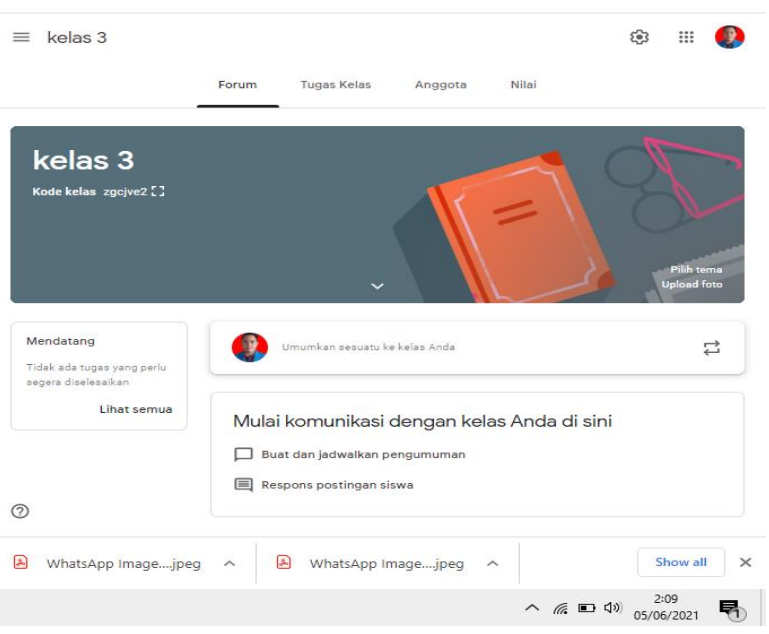

Gambar 6. Langkah Kelima

Untuk berinteraksi dengan siswa guru dapat memberikan kode kelas yang terdapat pada tampilan gambar 5 serta guru dapat memberikan tugas yang tersedia pada Google Classroom.

Setelah selesai pemberian materi dan praktik, seluruh peserta kembali diberikan pertanyaan mengenai pelaksanaan kegiatan pelatihan serta apakah materi mudah dipahami dan diaplikasi dalam proses pembelajaran. Setelah itu kegiatan pengabdian masyarakat dengan memberikan pelatihan perancangan media pembelajaran ditutup.

Capaian keberhasilan peserta pelatihan adalah kemampuan peserta dalam menggunakan Google Classroom dalam pembelajaran online. Capaian kinerja peserta dinilai berdasarkan indikator yaitu kemampuan mengoperasikan perangkat laptop atau komputer, membuat Google Classroom, memasukkan materi pembelajaran serta media, rancangan keterlibatan siswa, dan penilaian aktivitas belajar. Semua indikator ini tercapai oleh sebagian besar peserta.

Kegiatan PKM ini diharapkan dapat meningkatkan kemampuan guru untuk menggunakan media pembelajaran pada pembelajaran daring sehingga pembelajaran menjadi lebih menarik bagi siswa. Setelah pelatihan, para guru diarahkan untuk menggunakan Google Classroom dalam pembelajaran. Kegiatan ini dirancang untuk membekali guru dalam memanfaatkan teknologi yang dapat digunakan dalam proses pembelajaran daring di masa pandemi.

\section{SIMPULAN}

Pelatihan merancang media pembelajaran pada adaptasi kebiasaan baru di sekolah dasar kabupaten Buton mendapatkan sambutan positif dari pihak sekolah mitra. Selain itu, guru-guru yang menjadi peserta dalam kegiatan tersebut sangat mengapresiasi positif. Hal itu tampak dari pasrtisipasi peserta serta semangat yang ditunjukkan selama mengikuti kegiatan pelatihan. 
883 Peningkatan Kompetensi Guru dalam Merancang Media Pembelajaran pada Adaptasi Kebiasaan Baru di SD Kabupaten Buton- Andi Lely Nurmaya. G, Irsan, Muliati, Ahmad Fuadi

DOI: https://doi.org/10.31004/abdidas.v2i4.359

Guru sudah memiliki kemampuan atau kompotensi dalam membuat Google Classroom sebagai media pembelajaran. Kompotensi tersebut harus didukung pihak sekolah serta menyediakan fasilitas yang memadai seperti jaringan internet.

Selama pelatihan masih terdapat beberapa guru yang belum mampu membuat Google Classroom dengan baik oleh karena itu diperlukan kegiatan pelatihan lanjutan disertai pendampingan sehingga guru semakin mahir dalam menggunakan teknologi dalam proses pembelajaran

\section{UCAPAN TERIMA KASIH}

Ucapan terima kasih kami sampaikan setinggi-tinnginya kepala sang pencipta Allah SWT, pimpinan Universitas Muhamadiyah Buton atas dukungannya dalam kegiatan pengabdian masyarakat ini serta seluruh jajaran pihak mitra sekolah yang telah mendukung kegiatan ini.

\section{DAFTAR PUSTAKA}

Agustina, N., \& Jeruk, K. (n.d.). Peningkatan Kreativitas Guru Dalam Merancang Media Pembelajaran Dengan Menggunakan Powtoon Di Sd Pelita 2.

Inggriyani, F.-, Hamdani, A. R., \& Dahlan, T. (2019). Minat Belajar Mahasiswa dengan Menggunakan Blended Learning melalui Google Classroom pada Pembelajaran Konsep Dasar Bahasa Indonesia SD. PEMBELAJAR: Jurnal Ilmu Pendidikan, Keguruan, Dan Pembelajaran, 3(1), 28. https://doi.org/10.26858/pembelajar.v3i1.864 9

Purwati Zisca Diana, Denik Wirawati, Z. (2020). Desain pembelajaran berbasis daring pada masa pandemi Covid-19 di SMP Muhammadiyah se-Gunungkidul. Seminar Nasional Hasil Pengabdian Kepada Masyarakat, November, 237-244.
Sabran, \& Sabara, E. (2019). Keefektifan Google Classroom sebagai media pembelajaran. PROSIDING SEMINAR NASIONAL LEMBAGA PENELITIAN UNIVERSITAS NEGERI Makasar, 122-125. https://webcache.googleusercontent.com/sear ch?q=cache:SS_jKM_r2TAJ:https://ojs.unm. ac.id/semnaslemlit/article/download/8256/47 $67+\& \mathrm{~cd}=2 \& \mathrm{hl}=\mathrm{id} \& \mathrm{ct}=\mathrm{clnk} \& \mathrm{gl}=\mathrm{id}$

Utami, R. (2019). Analisis Respon Mahasiswa terhadap Penggunaan Google Classroom pada Mata Kuliah Psikologi Pembelajaran Matematika. Prisma, Prosiding Seminar Nasional Matematika ISSN 2613-9189, 2, 498-502.

https://journal.unnes.ac.id/sju/index.php/pris $\mathrm{ma} /$ article/view/29040 